\title{
Competitiveness Enhancement of The Small Enterprises of Dried Three-Spot Gourami (Trichogaster trichopterus) in Banjar Regency, South Kalimantan Province Through Improvement of The Process Technology, Managerial, and Business Culture
}

\author{
Agung Nugroho, Dessy Maulidya Maharani, Agung Cahyo Legowo, Febriani Purba \\ Jurusan Teknologi Industri Pertanian, Fakultas Pertanian, Universitas Lambung Mangkurat \\ Jl. Jend. Ahmad Yani Km. 36, Banjarbaru, Kalimantan Selatan 70714 \\ E-mail: anugroho@ulm.ac.id; dessymaulidyamaharani@ulm.ac.id; agung@ulm.ac.id; \\ febriani.purba@ulm.ac.id
}

Article History:
Received: Aug 7th 2020
Revised: Jan 11't 2021
Accepted: May 30 2021

Keywords: diversification,
three-spot gourami, added
value, community
empowerment, Trichogaster
trichopterus.

Article History:

Received: Aug 7th 2020

Revised: Jan 11th 2021

Accepted: May 30 2021

Keywords: diversification, three-spot gourami, added value, community trichopterus.
Abstract: Competitiveness enhancement of the dried three spot gourami producers in Banjar Regency, South Kalimantan Province was undertaken, because they are the least beneficiaries of the business system that has been run for generations. The competitiveness was developed through improvement of the production technology, managerial, and business culture. Technology enhancement was achieved by improving the drying method, product diversification, quality improvement, packaging improvement, and labeling. Managerial aspects developed included management in finance, resources, and marketing. Cultural development was focused on social behavior, namely education on the importance of investment and financial management so that the revenue obtained can be used as business assets again. Those efforts have effectively improved the indicators of business competitiveness, namely increasing income, increasing product added value, increasing innovation and creativity, raising awareness of quality, increasing managerial ability, and improving attitudes and enthusiasm for continuous improvement.

\section{Pendahuluan}

Kalimantan Selatan merupakan salah satu provinsi dengan potensi perikanan air tawar yang besar. Lebih dari 40\% luas wilayah provinsi ini terletak pada kemiringan 0 $2 \%$ dengan daerah yang identik dengan rawa. ${ }^{1}$ Selain itu, wilayah ini memiliki curah hujan rata-rata yang tinggi, yaitu sekitar $200 \mathrm{~mm}$. Dengan topografi yang didominasi

\footnotetext{
${ }^{1}$ Junius Akbar, Potensi dan Tantangan Budidaya Ikan Rawa di Kalimantan Selatan (Banjarmasin: Lambung Mangkurat University Press, 2014).
} 
dataran rendah dan menjadi jalur beberapa sungai besar dan rawa menjadikan wilayah Kalimantan Selatan terutama Kabupaten Banjar, sebagai kabupaten terluas, menjadi tempat yang ideal bagi hidupnya berbagai jenis ikan rawa. Salah satu jenis yang dominan adalah sepat rawa (Trichogaster trichopterus).

Masyarakat Kalimantan Selatan yang identik dengan masyarakat rawa dan sungai sangat akrab dengan ikan sepat rawa. Sesuai dengan namanya, ikan yang memiliki ukuran panjang 10-12 cm ini mudah sekali dijumpai di perairan rawa. Dalam bahasa Inggris, ikan sepat rawa disebut sebagai three spot gourami, karena memiliki ciri spesifik dengan hadirnya tiga titik/bulatan di sisi tubuhnya. ${ }^{2}$ Ikan ini digolongkan dalam kelompok herbivora. Dari bentuk jari-jari insang yang ramping, panjang, serta rapat, yang berjumlah antara 11-14 buah, maka ikan sepat rawa dapat menyaring plankton yang masuk dalam saluran pencernaannya. ${ }^{3}$

Masyarakat Banjar pada umumnya mengkonsumsi sepat rawa dengan digoreng atau dibuat balado dari sepat yang telah dikeringkan. Sepat kering dijual di berbagai pasar tradisional dan juga beberapa pusat produksi sepat di beberapa kabupaten di Kalimantan Selatan. Salah satu wilayah produktif penghasil ikat sepat di Kabupaten Banjar berada di Desa Tambak Baru Ulu, Kecamatan Martapura yang berjarak sekitar 5 km dari Kota Martapura (pusat kota Kabupaten Banjar) dan 15 km dari Kota Banjarbaru, serta $50 \mathrm{~km}$ dari Kota Banjarmasin. Posisi geografis dari wilayah ini, sebenarnya memberikan potensi pasar yang besar, karena berada di antara tiga tiga pusat bisnis di Kalimantan Selatan.

Produksi ikan sepat kering dimulai dari kegiatan penangkapan, kemudian pembersihan (penyiangan), penggaraman, dan pengeringan. Pada umumnya kegiatan penangkapan dilakuan oleh para suami di rawa-rawa yang tersebar sekitar tempat tinggalnya. Sementara proses pembersihan, penggaraman, dan pengeringan dilakukan oleh para istri. Produksi ikan sepat kering selama ini dilakukan secara turun temurun, dan mayoritas dijadikan sebagai pekerjaan sampingan yang dapat memberikan penghasilan tambahan.

Penggaraman dan pengeringan pada dasarnya dilakukan dengan tujuan untuk memperpanjang umur simpan produk. Penggaraman serta kadar air yang rendah akan menghambat pertumbuhan mikroba penyebab pembusukan ikan. ${ }^{4}$ Pada dasarnya, ikan

2 Junius Akbar, “Pengantar Ilmu Perikanan dan Kelautan (Budi Daya Perairan),” ed. Syachradjad Fran (2016).

${ }^{3}$ Akhmad Murjani, "Budidaya Beberapa Varietas Ikan Sepat Rawa (Trichogaster trichopterus Pall) dengan Pemberian Pakan Komersial," Fishscientiae 1, no. 2 (2011): 214-232.

${ }^{4}$ Rezal Fahmi, Agung Nugroho, dan Alia Rahmi, "Rancang Bangun dan Uji Kinerja Pengering Ikan Asin Sepat Rawa (Trichogaster trichopterus) Tipe Rak Bertingkat," in Seminar Nasional Teknologi \& Inovasi Industri 2018, vol. 1 (Banjarbaru: Balai Riset dan Standarisasi Industri Banjarbaru, 2018), 131140. 
sangat mudah mengalami penurunan mutu dikarenakan kadar airnya yang tinggi (lebih dari 75\%), pH yang netral, tekstur daging yang lunak, serta kandungan nutrisi yang tinggi, sehingga menjadi tempat yang sangat baik untuk pertumbuhan bakteri. ${ }^{5}$

Proses produksi ikan sepat kering di Desa Tambak Ulu dilakukan secara turun temurun dengan metode tradisional yang kurang memperhatikan aspek efektivitas, mutu produk dan higienitas. Pengeringan dilakukan secara konvensional dengan mengandalkan sinar matahari di atas meja pengering yang terbuat dari anyaman bambu dengan lebar $1 \mathrm{~m}$ dan panjang hingga $5 \mathrm{~m}$. Jika panas cukup terik sepanjang hari, pengeringan dapat dilakukan selama 1-2 hari sampai kadar airnya di bawah 20\%. Namun jika cuaca mendung atau hujan, pengeringan tidak berjalan maksimal dan harus diulang di hari-hari berikutnya. Hal ini yang terkadang menyebabkan ikan membusuk karena terlalu lama dalam kondisi basah.

Tingginya kadar air dan kandungan nutrisi dalam ikan memicu kerusakan mutu oleh aktivitas mikroorganisme dan enzim selama proses penjemuran yang tidak maksimal. ${ }^{6} \mathrm{Hal}$ ini menyebabkan penurunan mutu yang ditandai dengan munculnya bau amis sampai pembusukan. Penurunan mutu ini juga dapat disebabkan karena kontaminasi serangga seperti lalat selama proses pengeringan yang dilakukan secara terbuka. ${ }^{7}$ Dampak kekurangan tersebut menyebabkan ikan sepat kering berkualitas rendah karena cenderung berwarna gelap, terkontaminasi semut, kotoran, dan berbau amis.

Selain permasalahan mutu, tata niaga pemasaran produk ikan sepat kering juga menyimpan permasalahan. Selama ini masyarakat Desa Tambak Ulu menjual ikan sepat kering kepada tengkulak selain yang dijual secara langsung melalui beberapa warung sederhana yang didirikan menghadap ke jalan poros desa. Pada puncak musim panen, harga sepat kering sangatlah rendah, yaitu hanya mencapai Rp20.000,00/kg. Padahal 1 $\mathrm{kg}$ sepat kering harus dihasilkan melalui pengeringan dari sekitar $5 \mathrm{~kg}$ sepat basah. Dengan demikian, nilai tambah dari ikan sepat dan keuntungan yang diperoleh masyarakat sangatlah rendah. Penjualan dilakukan secara curah tanpa pengemasan yang memadai, serta belum ada usaha diversifikasi menjadi produk lain yang memberikan nilai tambah lebih tinggi.

Permasalahan mutu produk, rendahnya teknologi pengolahan, nilai tambah, serta pengelolaan yang terjadi di kelompok perajin ikan sepat di Desa Tambak Ulu, Kecamatan

${ }^{5}$ Angga Riansyah, Agus Supriadi, dan Nopianti Rodiana, "Pengaruh Perbedaan Suhu dan Waktu Pengeringan Terhadap Karakteristik Ikan Asin Sepat Siam (Trichogaster pectoralis) dengan Menggunakan Oven," Fishtech 2, no. 1 (2013): 53-68.

${ }^{6}$ Made Ricki Murti, "Performansi Pengering Ikan Aliran Alami memanfaatkan Energi Kombinasi Kolektor Surya dan Tungku Biomassa," Jurnal Energi Dan Manufaktur 4, no. 2 (2012).

${ }^{7}$ Riansyah, Supriadi, dan Rodiana, "Pengaruh Perbedaan Suhu dan Waktu Pengeringan Terhadap Karakteristik Ikan Asin Sepat Siam (Trichogaster pectoralis) dengan Menggunakan Oven.” 
Martapura, Kabupaten Banjar, menyebabkan daya saing usaha mereka menjadi lemah di hadapan para tengkulak dan juga produsen bermodal besar yang mampu memproduksi produk sepat kering dengan mutu dan kemasan yang lebih baik. Untuk itu diperlukan upaya peningkatan daya saing dari kelompok usaha dengan menitikberatkan pada penyelesaian masalah teknologi proses untuk peningkatan mutu, nilai tambah, dan diversifikasi produk, penguatan manajerial, serta budaya bisnisnya. Ketiga fokus ini merepresentasikan sikap-sikap kewirausahaan yang menjadi faktor penting dalam meningkatkan kesejahteraan masyarakat. ${ }^{8}$

\section{Metode}

Guna mencapai tujuan dari kegiatan pemberdayaan masyarakat ini, pendekatan yang digunakan adalah Asset Based Community Development (ABCD). Melalui paradigma ini, kekuatan yang dimiliki kelompok menjadi modal dasar dalam pengembangan dengan dimulai dari proses penyadaran, identifikasi, pemahaman, internalisasi, untuk selanjutnya digunakan sebagai energi dalam mobilisasi pergerakan kelompok untuk mencapai tujuan yang dicanangkan. ${ }^{9}$ Paradigma ini dipilih berdasarkan pada analisis kondisi dan permasalahan yang dihadapi kelompok masyarakat perajin sepat kering Desa Tambak Ulu, Kecamatan Martapura, Kabupaten Banjar. Dalam implementasinya, pendekatan ABCD ini dilakukan melalui beberapa tahapan yaitu pemetaan aset, persiapan program, program pelatihan dan transfer teknologi, implementasi teknologi, penguatan kelompok, dan evaluasi, serta tindakan perbaikan. ${ }^{10}$ Berdasarkan pada analisis permasalahan kelompok serta pemetaan aset yang dimiliki, maka dirumuskan strategi programnya seperti tersaji pada Gambar 1.

Peran serta seluruh komponen tentunya sangat diperlukan, baik keseriusan, motivasi, kerja keras masyarakat, kepedulian, keseriusan pemerintah daerah, dan juga peran yang intensif dari perguruan tinggi. Program yang diimplementasikan harus memenuhi prinsip implementatif, sederhana, tidak berbiaya tinggi, dan memiliki nilai tambah yang lebih tinggi. Program diimplementasikan melalui kegiatan Penerapan Teknologi Tepat Guna Kepada Masyarakat. Secara lebih detail alur pelaksanaan kegiatan disajikan pada Gambar 2.

${ }^{8}$ Sukidjo Sukidjo, "Peran Pendidikan Kewirausahaan Dalam Pemberdayaan Masyarakat Miskin di Indonesia," Jurnal Economia 8, no. 1 (2012): 33-41.

${ }_{9}^{9}$ Nurul Inayah et al., "Penguatan Kelembagaan dan Pengembangan Potensi Ekonomi Masyarakat melalui Pengelolaan Saluran Irigasi Menjadi Wisata Literasi pada Kelompok Budidaya Ikan (POKDAKAN) 'Banyu Bening' Jajag Banyuwangi," Engagement: Jurnal Pengabdian Kepada Masyarakat 4, no. 1 (2020): 252-265.

${ }^{10}$ Mei Lina Fitri Kumalasari, Abdul Muhid, dan Funsu Andiarna, “Community Mentoring Through Efforts to Use The Waste of Cow Dung Into Biogas and Organic Fertilizer Towards Energy Independent Society," Engagement: Jurnal Pengabdian Kepada Masyarakat 4, no. 1 (2020): 1-13. 


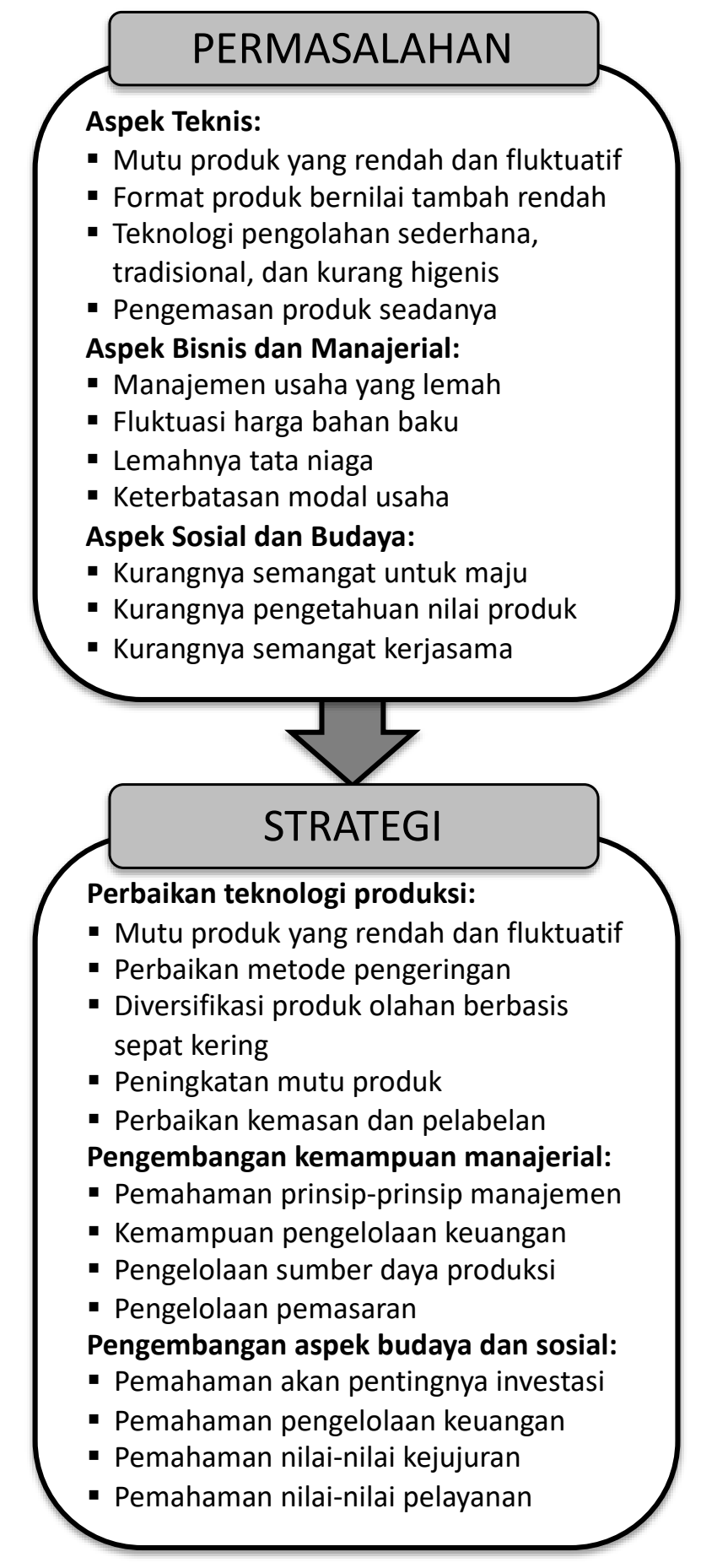

Gambar 1. Analisis permasalahan dan strategi penyelesaian masalahnya. 


\section{Tahap 1}

- Focus Group Discussion dengan anggota mitra untuk menyamakan persepsi mengenai permasalahan dan solusi.

\section{Tahap 2}

- Perencanaan bersama untuk implementasi program terkait waktu dan kesiapan sumber daya.

\section{$\downarrow$}

Tahap 3

- Transfer I: Pemahaman umum mengenai produk, teknologi proses, pemasaran dan promosi, serta manajemen usaha.

\section{Tahap 4}

- Transfer II: Pelatihan produksi, pengenalan peralatan, pengawasan mutu bahan baku, pengendalian proses, packaging dan pelabelan.

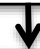

Tahap 5

- Transfer III: Pelatihan mengenai desain packaging, metode promosi, jaringan pemasaran, dan perencanaan produksi.

\section{Tahap 6}

- Transfer IV: Pelatihan manajemen organisasi, manajemen keuangan dan akuntansi, standarisasi, dan sertifikasi.

\section{Tahap 7}

- Pendampingan kelompok: proses produksi, pengawasan mutu, pemasaran, dan kinerja organisasi.

Tahap 8

- Evaluasi kinerja: produksi, mutu produk, respon pasar, kinerja organisasi, peluang dan pengembangan bisnis.

\section{$\downarrow$}

Tahap 9

- Perencanaan pengembangan berbasis evaluasi kinerja dan peluang pengembangan, termasuk pengembangan untuk implemetasi di kelompok lain atau Gapoktan lain.

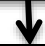

Tahap 10

- Penyusunan standarisasi produk dan proses.

- Penyusunan pola/model untuk duplikasi implementasi.

Gambar 2. Alur proses pelaksanaan kegiatan berdasarkan strategi yang ditetapkan. 
Teknologi proses yang akan akan ditransfer adalah pengering ikan sepat berbasis tenaga surya dan tungku api yang telah dikembangkan sebelumnya ${ }^{11}$ melalui penelitian dalam rangka mengahasilkan ikan sepat kering mutu premium dengan ciri warna yang lebih cerah, bersih (bebas benda asing), serta variasi produk yang lebih beragam baik dari segi ukuran maupun tingkat keringnya ${ }^{12}$. Gambar alat pengering yang ditransfer kepada masyarakat beserta kegiatan pelatihan teknis lainnya disajikan pada Gambar 3.

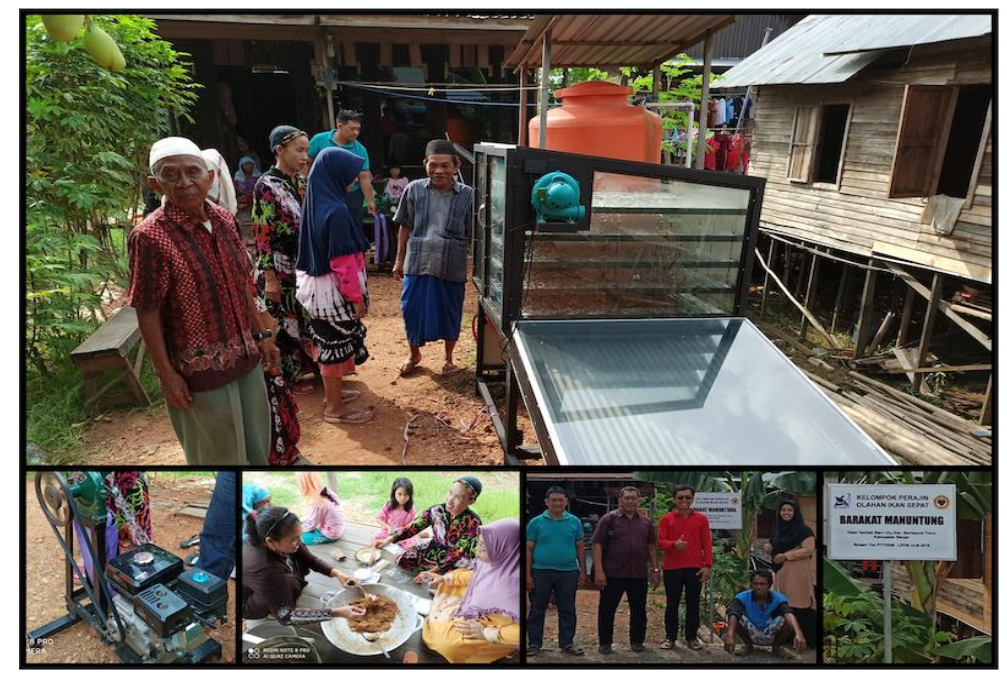

Gambar 3. Kegiatan transfer teknologi kepada masyarakat.

Pengembangan kemampuan manajemen usaha dilakukan melalui transfer pengetahuan, pelatihan, dan pendampingan dalam berbagai aspek manajemen yang meliputi perencanaan produksi, kendali mutu proses dan produk, pemasaran dan promosi, akuntansi dan manajemen keuangan, serta manajemen organisasi. ${ }^{13}$

Prinsip continuous improvement dan plan-do-check action harus diterapkan dalam program-program pemberdayaan masyarakat melalui pengembangan kapasitas. ${ }^{14}$ Tanpa pendampingan, pengawasan, dan evaluasi berkelanjutan program transfer teknologi hanya akan menjadi sebuah kegaitan seremonial tanpa adanya keberlanjutan. Untuk itu kegiatan pengabdian dilakukan melalui pendampingan, evaluasi, dan arahan-arahan untuk tindakan perbaikan baik dari aspek teknologi proses, pengendalian mutu, pemasaran, dan manajemen industri kecilnya.

${ }^{11}$ Fahmi, Nugroho, dan Rahmi, "Rancang Bangun dan Uji Kinerja Pengering Ikan Asin Sepat Rawa (Trichogaster trichopterus) Tipe Rak Bertingkat."

12 Dahlia Puspita Sari, Rodiana Nopianti, dan Ace Baehaki, "Karakteristik Sensori dan FisikoKimia Crackers dengan Penambahan Tepung Ikan Sepat Siam (Trichogaster pectoralis)," Fishtech 6, no. 2 (2017): 115-125.

${ }^{13}$ Hasbullah Hasbullah, "Konsep Diri dan Orientasi Tujuan sebagai Faktor Penting dalam Orientasi Umpan Balik Manajer dalam Mendukung Proses PDCA," Journal of Chemical Information and Modeling 10, no. 3 (2016): 294-310.

14 Diana Porwanti Siswanto dan Debora Aysia, "PDCA sebagai Upaya Peningkatan Target Perusahaan Plant B di PT X," Jurnal Jitra 2, no. 2 (2014): 129-134. 


\section{Hasil}

Fokus kegiatan pengabdian yang dilakukan adalah pemberdayaan masyarakat melalui peningkatan nilai tambah dari produk sepat kering yang selama ini menjadi penghasilan tambahan masyarakat. Target yang ingin dicapai adalah terbentuknya kelompok masyarakat perajin olahan ikan sepat yang memproduksi produk-produk bernilai tambah tinggi, bermutu, dan berdampak dalam peningkatan penghasilan. Untuk mencapai sasaran tersebut dilakukan melalui pengembangan terintegrasi pada aspek teknologi produksi, manajerial, dan budaya bisnis.

\section{Perbaikan Teknologi Proses}

Perbaikan teknologi produksi dilakukan melalui perbaikan metode pengeringan, diversifikasi produk olahan berbasis sepat kering, peningkatan mutu produk, serta perbaikan kemasan dan pelabelan. Perbaikan metode pengeringan dilakukan dengan mengganti metode pengeringan konvensional menggunakan meja pengering terbuka dengan penggunaan alat pengering model rak kombinasi tenaga surya dan tungku (Gambar 3). Metode pengeringan konvensional memiliki beberapa kelemahan, seperti ketergantungan terhadap cuaca, tidak higienis, serta tingkat produk terbuang (reject) yang tinggi (di atas 10\%).

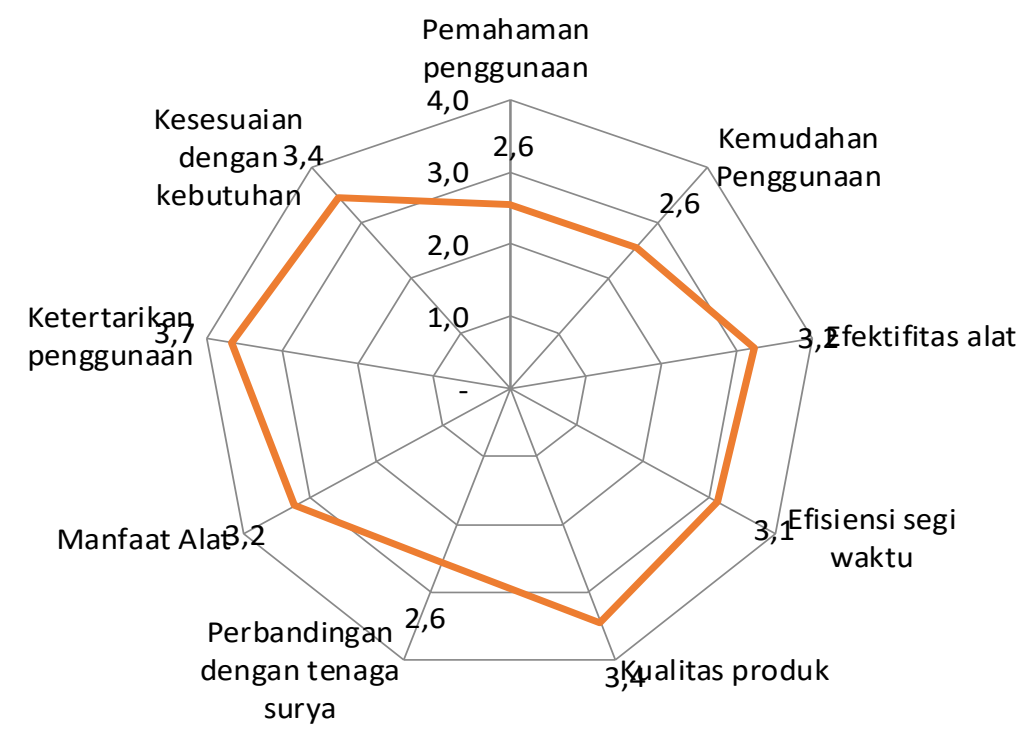

Gambar 4. Grafik respon masyarakat atas adanya pengenal peralatan baru alam meningkatkan nilai tambah produk.

Pengeringan menggunakan pengering model rak kombinasi surya-tungku dapat mengatasi permasalahan sebelumnya. Pengeringan tidak lagi tergantung pada cuaca, karena adanya kombinasi sumber panas dari panas matahari dan tungku dari kompor 
gas $^{15}$. Produk yang dikeringkan seluruhnya tertutup kaca, sehingga lebih higienis. Produk aman dari kontaminasi baik yang bersifat biologis, kimia, maupun fisika. Selain itu, persentase produk rusak (reject) dapat ditekan hingga di bawah 3\%. Respon penerimaan atas adanya transfer ke peralatan pengering model rak kombinasi surya-tungku dianalisis berdasarkan masukan masyarakat melalui kuesioner. Adapun hasil evaluasi yang diperoleh disajikan pada Gambar 4. Terlihat bahwa respon masyarakat untuk keseluruhan aspek teknis cukup baik dan yang terpenting adalah pada nilai kesesuaian dengan kebutuhan kelompok dengan nilai yang baik $(3,4)$.

Kerusakan produk ikan sepat paling dominan disebabkan oleh pembusukan karena kadar air yang tidak segera turun selama pengeringan. Ikan sepat bersih sebelum dikeringkan memiliki kadar air di atas 70\%. Sementara untuk keamanan penyimpanan kadar air sepat kering maksimal 20\%. Tabel 1 menyajikan kadar air dan kadar abu ikan sepat sebelum dan sesudah pengeringan dengan pengering rak kombinasi surya-tungku.

Tabel 1. Kadar air dan kadar abu ikan sepat sebelum dan sesudah pengeringan.

\begin{tabular}{llc}
\hline Perlakuan & Parameter & Nilai (\%) \\
\hline \multirow{2}{*}{ Sebelum pengeringan } & Kadar air & 73,58 \\
& Kadar abu & 13,95 \\
\hline \multirow{2}{*}{ Setelah pengeringan } & Kadar air & 19,37 \\
& Kadar abu & 21,91 \\
\hline
\end{tabular}

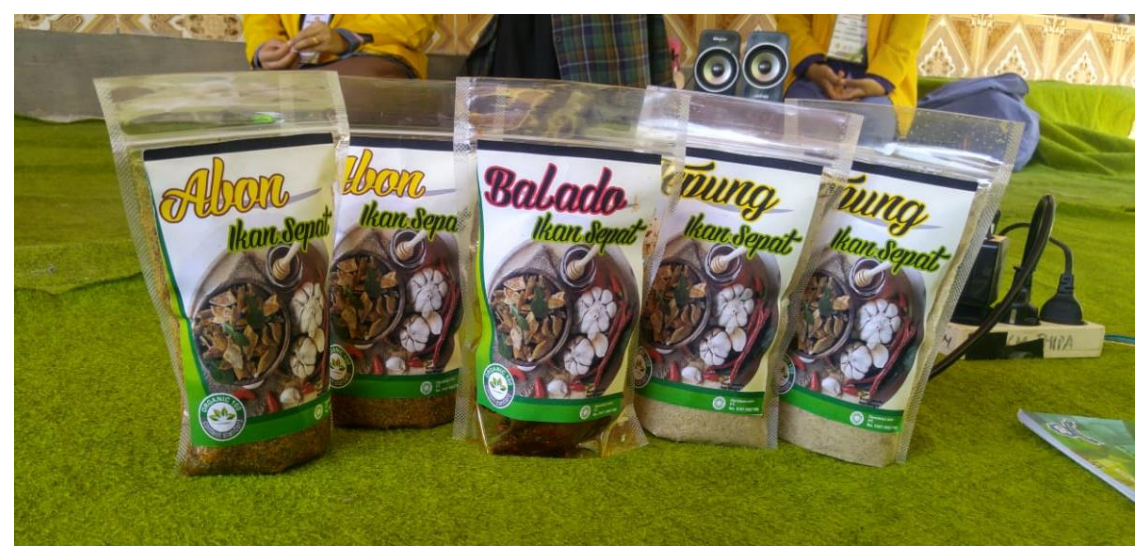

Gambar 5. Diversifikasi dan peningkatan mutu serta kemasan produk yang telah dilakukan.

Diversifikasi produk dilakukan dengan formulasi produk-produk olahan turunan dari sepat kering. Produk yang berhasil dikembangkan adalah tepung sepat dan abon sepat (Gambar 5). Diversifikasi produk ditujukan untuk meningkatkan nilai tambah. Pada

${ }^{15}$ Efrida Basri dan Achmad Supriadi, "Uji Coba Mesin Pengering Kayu Kombinasi Tenaga Surya dan Panas dari Tungku Tipe I," Jurnal Penelitian Hasil Hutan 24, no. 5 (2006): 437-448. 
puncak musim panen, selama ini $1 \mathrm{~kg}$ sepat kering hanya dihargai sebesar Rp20.000,00. Sementara, $1 \mathrm{~kg}$ sepat kering dihasilkan dari pengeringan sekitar $5 \mathrm{~kg}$ sepat segar. Hal ini tentunya tidak memberikan keuntungan yang cukup bagi masyarakat. Dengan dibuat abon, maka nilai tambah sepat kering dapat meningkat lebih dari 5 kali lipat. Abon sepat dijual dengan harga Rp200.000,00/kg. Sementara itu $1 \mathrm{~kg}$ sepat kering jika dibuat abon menghasilkan 1,5 kg abon. Adapun karakteristik proksimat dari tepung dan abon sepat disajikan pada Tabel 2.

Tabel 2. Peningkatan nilai tambah dan karakteristik produk olahan sepat kering.

\begin{tabular}{lclc}
\hline Produk olahan & Peningkatan nilai tambah*(\%) & Parameter proksimat & Nilai (\%) \\
\hline \multirow{3}{*}{ Tepung sepat } & \multirow{2}{*}{200} & Kadar air & 4,05 \\
& & Kadar abu & 34,45 \\
& & Kadar lemak & 12,65 \\
& \multirow{2}{*}{500} & Kadar protein & 38,60 \\
\hline \multirow{2}{*}{ Abon sepat } & & Kadar air & 5,56 \\
& & Kadar abu & 9,28 \\
& & Kadar lemak & 38,65 \\
& & Kadar protein & 22,31 \\
\hline
\end{tabular}

*Peningkatan nilai tambah dihitung berdasarkan perbandingan harga jual produk olahan setelah dikurangi biaya produksi dengan harga sepat kering rata-rata (Rp20.000,00/kg).

Tepung sepat meskipun nilai tambahnya relatif lebih rendah, namun peluang pasar dan pemanfaatannya jauh lebih luas 16 . Tepung sepat dapat digunakan sebagai bahan baku kerupuk ikan, mie, amplang, bakso ikan, nugget, dan juga sebagai campuran bubur dan makanan lainnya. Untuk tepung sepat dijual Rp75.000,00/kg. Nila tambahnya mencapai lebih dari 2 kali lipat. Tepung ikan sepat memiliki banyak manfaat dalam pemenuhan nutrisi karena kandungan ikan sepat sendiri yang kaya akan protein, lemak, dan mineral.

\section{Pengembangan Kapasitas Manajerial dan Budaya Bisnis}

Pengembangan kapasitas manajerial meliputi pengembangan kemampuan dalam pengelolaan keuangan, pengelolaan sumber daya produksi, termasuk sumber daya manusia (SDM), bahan baku (material), dan peralatan (mesin), serta pengelolaan pemasaran. Sementara itu pengembagan budaya bisnis ditujukan pada aspek kesadaran akan pentingnya pengelolaan keuangan dan investasi serta pentingnya nilai-nilai kejujuran dan pelayanan. Masyarakat diberikan pemahaman akan arti pentingnya dan dampak dari pengelolaan sumber daya yang baik. Masyarakat diberikan keterampilan dalam mengelola dan melakukan pencatatan keuangan, rekaman proses, catatan

16 Sari, Nopianti, dan Baehaki, "Karakteristik Sensori dan Fisiko-Kimia Crackers dengan Penambahan Tepung Ikan Sepat Siam (Trichogaster pectoralis)." 
penggunaan bahan baku, mesin, dan juga catatan pemasaran. Pemahaman nilai-nilai kejujuran dan pelayanan diberikan karena ini menjadi dasar budaya dalam mewujudkan masyarakat yang maju. Tabel 3 menyajikan perubahan kondisi dari aspek-aspek perubahan kemampuan manajerial dan budaya bisnis yang berhasil diamati dan dibandingkan antara sebelum dan sesudah program.

Tabel 3. Deskripsi perubahan situasi dan kondisi terkait aspek manajerial dan budaya bisnis pada pra dan pasca program.

\section{Aspek Perubahan Deskripsi Kondisi}

\section{Pra Program Pasca Program}

\begin{tabular}{lll}
\hline Pengelolaan keuangan & $\begin{array}{l}\text { Tidak ada pencatatan dan } \\
\text { perencanaan keuangan }\end{array}$ & $\begin{array}{l}\text { Telah ada pencatatan dan } \\
\text { perencanaan keuangan sederhana }\end{array}$ \\
\hline Pengelolaan SDM & $\begin{array}{l}\text { Tidak ada pembagian tugas, } \\
\text { tanggung jawab, wewenang, } \\
\text { dan hak yang jelas }\end{array}$ & $\begin{array}{l}\text { Telah ada pembagian tugas, } \\
\text { tanggung jawab, wewenang, dan } \\
\text { hak yang jelas dalam struktur } \\
\text { kelompok melalui kesepakatan } \\
\text { bersama }\end{array}$
\end{tabular}

\begin{tabular}{lll}
\hline $\begin{array}{l}\text { Pengelolaan bahan } \\
\text { baku }\end{array}$ & Tidak ada perencanaan & Mulai dilakukan proses \\
& produksi dan bahan baku & $\begin{array}{l}\text { perencanaan produksi berikut } \\
\text { dengan perencanaan } \\
\text { ketersediaan bahan }\end{array}$ \\
&
\end{tabular}

Pengelolaan peralatan Tidak ada jadwal perawatan $\quad$ Telah dilakukan sistem alat terstruktur. perawatan terjadwal serta Tidak ada standar kebersihan alat standar kebersihan alat berikut dengan SOP-nya

\begin{tabular}{lll}
\hline $\begin{array}{l}\text { Pengelolaan } \\
\text { pemasaran }\end{array}$ & $\begin{array}{l}\text { Tidak ada pengembangan } \\
\text { strategi pemasaran, } \\
\text { pengemasan sangat } \\
\text { sederhana, tidak ada label }\end{array}$ & $\begin{array}{l}\text { Strategi pemasaran mulai } \\
\text { dijalankan melalui berbagai jalur } \\
\text { terutama media digital. } \\
\text { Pengemasan dengan bahan dan } \\
\text { desain yang modern. }\end{array}$ \\
\hline Kesadaran investasi & $\begin{array}{l}\text { Tidak ada program dan } \\
\text { kesadaran untuk melakukan } \\
\text { investasi }\end{array}$ & $\begin{array}{l}\text { Mulai ada kesadaran untuk } \\
\text { melakukan investasi walaupun } \\
\text { dalam jumlah yang kecil tetapi } \\
\text { telah terprogram dengan baik }\end{array}$ \\
& Konsep pelayanan tradisional & $\begin{array}{l}\text { Mulai ada pemahaman dan } \\
\text { kesadaran akan pentingnya } \\
\text { pelayanan terbaik kepada } \\
\text { kilai-nilai pelayananen serta adanya }\end{array}$ \\
& & $\begin{array}{l}\text { kerubahan pola pelayanan baik } \\
\text { secara verbal maupun non-verbal } \\
\text { serta komitmen akan mutu. }\end{array}$ \\
& &
\end{tabular}




\section{Diskusi}

Peningkatan mutu produk dimulai dengan penanaman pola fikir masyarakat akan budaya mutu. Produk yang bermutu akan memberikan nilai tambah yang tinggi. Mutu produk merupakan hasil dari rangkaian pengendalian mutu mulai bahan baku, proses, dan produk jadinya. Mutu produk olahan sepat dijaga mulai dari proses pembersihan, pengeringan, penepungan, pembuatan abon, hingga pengemasan. Masyarakat diberikan pemahaman, pengertian, dampak serta teknik-teknik dalam pengendalian mutu ini. Usaha ini juga mampu meningkatkan karakter masyarakat dalam kehidupan sehari-hari serta mampu mengubah karakter produk yang dihasilkan menjadi produk yang lebih bermutu baik dari karakteristik produk maupun kemasannya. Selain itu diversifikasi produk telah berhasil dilakukan untuk meningkatkan nilai tambahnya hingga 500\%.

Kemampuan manajerial dan budaya bisnis menjadi hal yang sangat mendasar dalam pengelolaan suatu unit usaha terutama yang dilakukan secara kelompok. Pemahaman dan kesadaran akan arti pentingnya pengelolaan sumber daya produksi merupakan sesuatu yang sangat penting. Beberapa kemampuan manajerial yang harus dimiliki antara lain kemampuan dalam mengelola dan melakukan pencatatan keuangan, rekaman proses, penggunaan bahan baku, perawatan mesin, dan juga pemasaran. Dengan tertibnya pengelolaan administrasi maka kegiatan dapat dievaluasi dengan baik. Dengan demikian, perencanaan kegiatan berikutnya dapat dilakukan melalui penerapan pola siklus manajemen plan, do, check, dan action ${ }^{17}$.

Pengembangan aspek budaya bisnis sebenarnya telah terjadi pada saat pengembangan aspek manajerial. Pada dasarnya perilaku yang dituntut dalam sistem manajemen yang tertib harus menjadi sebuah kebiasaan (habit) dan selanjutnya menjadi pola budaya dan sosial dalam masyarakat ${ }^{18}$. Pengembangan budaya bisnis secara spesifik diberikan melalui pemahaman akan pentingnya investasi dan pengelolaan keuangan, sehingga hasil yang diperoleh dapat menjadi asset usaha kembali. Pemahaman nilai-nilai kejujuran dan pelayanan juga diberikan, karena ini menjadi dasar budaya yang positif yang menjadi dasar budaya masyarakat yang maju.

Melaui strategi yang dilakukan, yaitu perbaikan pada aspek teknologi produksi, pengembangan aspek manajerial, serta pembinaan aspek budaya bisnis, kegiatan pemberdayaan masyarakat ini telah berhasil memperbaiki beberapa aspek penting dalam peningkatan karakter masyarakat. Tingkat kesejahteraan belum dapat diukur dalam waktu yang relatif singkat, namun tanda-tanda yang mengindikasikan adanya

${ }^{17}$ Siswanto dan Aysia, "PDCA sebagai Upaya Peningkatan Target Perusahaan Plant B di PT X."

${ }^{18}$ Sukidjo, "Peran Pendidikan Kewirausahaan Dalam Pemberdayaan Masyarakat Miskin di 
peningkatan kesejahteraan telah terlihat ${ }^{19}$. Beberapa sinyalemen itu antara lain peningkatan pendapatan dalam penjualan produk olahan sepat, peningkatan kreativitas, peningkatan kepedulian akan mutu, serta yang paling penting adalah semangat masyarakat untuk terus meningkatkan perbaikan usaha.

\section{Simpulan}

Pemberdayaan masyarakat pada sentra produksi olahan ikan sepat di Martapura, Kabupaten Banjar dilakukan melalui konsep yang terintegrasi yaitu melalui pengembangan pada aspek teknologi produksi, aspek manajerial, dan budaya bisnis. Strategi yang dilakukan dinilai efektif dalam meningkatkan pendapatan kelompok usaha sebesar $40 \%$ melalui penguatan nilai tambah produk, peningkatan inovasi dan kreativitas, peningkatan kepedulian akan mutu, peningkatan kemampuan manajerial, serta perbaikan nilai-nilai bisnis yaitu kejujuran dan pelayanan. Upaya ini perlu terus dijaga dan ditingkatkan melalui penerapan konsep manajemen plan, do, check, dan action sehingga bisnis akan terus berkembang dan mampu memberikan dampak yang lebih luas di masyarakat.

\section{Pengakuan}

Ungkapan terima kasih disampaikan kepada Direktorat Riset dan Pengabdian Masyarakat atas pendanaan kegiatan pengabdian kepada masyarakat yang telah diberikan melalui Program Penerapan Teknologi Tepat Guna kepada Masyarakat Tahun 2019.

${ }^{19}$ Ikeu Tanziha, "Model Pemberdayaan Petani Menuju Ketahanan Pangan Keluarga," Jurnal Gizi dan Pangan 6, no. 1 (2011): 90. 


\section{Daftar Referensi}

Akbar, Junius. "Pengantar Ilmu Perikanan dan Kelautan (Budi Daya Perairan).” Diedit oleh Syachradjad Fran (2016).

-_- Potensi dan Tantangan Budidaya Ikan Rawa di Kalimantan Selatan. Banjarmasin: Lambung Mangkurat University Press, 2014.

Basri, Efrida, dan Achmad Supriadi. "Uji Coba Mesin Pengering Kayu Kombinasi Tenaga Surya dan Panas dari Tungku Tipe I." Jurnal Penelitian Hasil Hutan 24, no. 5 (2006): 437-448.

Fahmi, Rezal, Agung Nugroho, dan Alia Rahmi. "Rancang Bangun dan Uji Kinerja Pengering Ikan Asin Sepat Rawa (Trichogaster trichopterus) Tipe Rak Bertingkat." In Seminar Nasional Teknologi \& Inovasi Industri 2018, 1:131-140. Banjarbaru: Balai Riset dan Standarisasi Industri Banjarbaru, 2018.

Hasbullah, Hasbullah. "Konsep Diri dan Orientasi Tujuan sebagai Faktor Penting dalam Orientasi Umpan Balik Manajer dalam Mendukung Proses PDCA." Journal of Chemical Information and Modeling 10, no. 3 (2016): 294-310.

Inayah, Nurul, Nawal Ika Susanti, M. Rizkon Al Musafiri, dan Lely Ana Ferawati Ekaningsih. "Penguatan Kelembagaan dan Pengembangan Potensi Ekonomi Masyarakat melalui Pengelolaan Saluran Irigasi Menjadi Wisata Literasi pada Kelompok Budidaya Ikan (POKDAKAN) 'Banyu Bening' Jajag Banyuwangi." Engagement: Jurnal Pengabdian Kepada Masyarakat 4, no. 1 (2020): 252-265.

Kumalasari, Mei Lina Fitri, Abdul Muhid, dan Funsu Andiarna. "Community Mentoring Through Efforts to Use The Waste of Cow Dung Into Biogas and Organic Fertilizer Towards Energy Independent Society." Engagement: Jurnal Pengabdian Kepada Masyarakat 4, no. 1 (2020): 1-13.

Murjani, Akhmad. "Budidaya Beberapa Varietas Ikan Sepat Rawa (Trichogaster trichopterus Pall) dengan Pemberian Pakan Komersial." Fishscientiae 1, no. 2 (2011): 214-232.

Murti, Made Ricki. "Performansi Pengering Ikan Aliran Alami memanfaatkan Energi Kombinasi Kolektor Surya dan Tungku Biomassa." Jurnal Energi Dan Manufaktur 4, no. 2 (2012).

Riansyah, Angga, Agus Supriadi, dan Nopianti Rodiana. "Pengaruh Perbedaan Suhu dan Waktu Pengeringan Terhadap Karakteristik Ikan Asin Sepat Siam (Trichogaster pectoralis) dengan Menggunakan Oven." Fishtech 2, no. 1 (2013): 53-68.

Sari, Dahlia Puspita, Rodiana Nopianti, dan Ace Baehaki. "Karakteristik Sensori dan Fisiko-Kimia Crackers dengan Penambahan Tepung Ikan Sepat Siam (Trichogaster pectoralis)." Fishtech 6, no. 2 (2017): 115-125. 
Siswanto, Diana Porwanti, dan Debora Aysia. "PDCA sebagai Upaya Peningkatan Target Perusahaan Plant B di PT X.” Jurnal Jitra 2, no. 2 (2014): 129-134.

Sukidjo, Sukidjo. "Peran Pendidikan Kewirausahaan Dalam Pemberdayaan Masyarakat Miskin di Indonesia." Jurnal Economia 8, no. 1 (2012): 33-41.

Tanziha, Ikeu. "Model Pemberdayaan Petani Menuju Ketahanan Pangan Keluarga." Jurnal Gizi dan Pangan 6, no. 1 (2011): 90. 